Отримано: 10 грудня $2021 \mathrm{p}$.

Прорецензовано: 16 грудня 2021 р.

Прийнято до друку: 17 грудня 2021 р.

e-mail: Liudavolkova@gmail.com

DOI: $10.25264 / 2519-2558-2021-12(80)-163-165$
Volkova L. V. Communicative aspect of foreign language learning process. Наукові записки Національного університету «Острозька академія»: серія "Філологія». Острог : Вид-во НаУОА, 2021. Вип. 12(80). С. 163-165.

Liudmyla Volkova,

Ph.D., Associate Professor of the Department for Modern European Languages, University of State Fiscal Service of Ukraine

\title{
COMMUNICATIVE ASPECT OF FOREIGN LANGUAGE LEARNING PROCESS
}

The importance of forming foreign language communicative competence in the context of professional training has been ascertained for efficient usage in learning process of foreign language. The efficiency of communicative aspect in the educational process of higher education is proved, as it provide an opportunity to form professional skills of future professionals, involving them in intensive cognitive, intellectual and creative activity. Communicative activity is considered as a process of solving a number of professional tasks by students. This activity is aimed at achieving a common goal - training, education and personal development of a student. The aim of the communicative activity is the formation of foreign language communicative competence using of the theoretical material in solving professional problems. The importance of understanding the main structural elements of communicative activity have been ascertained for its efficient usage in learning process of foreign language. The article highlights the problems associated with different methods and techniques of communicative-based learning. The communicative activity approach of learning foreign languages is particular important. It is based on the fact that learning is a model of communication. The basic principles of its implementation as a communicative teaching method of speaking are analyzed. It should be noted that communicative and active approach to learning foreign languages is one of the most significant and effective. Through communicative methods, lessons can be more interesting and various. This means that students will have interest in further understanding and learning. Communicative nature of communication is that learning is a model of the communication process. Communicative orientation of learning process is a prerequisite of success in practical learning of a foreign language. Communicative activity approach is based on the fact that learning is a model of communication. The communicative method of teaching activities is based on the main principles which are analyzed below.

Key words: foreign language communicative competence, professional training, communicative method, learning process of foreign language.

Волкова Людмила Вікторівна,

кандидат педагогічних наук, дочент кафедри сучасних європейських мов, Університет державної фіскальної служби України

\section{КОМУНІКАТИВНА СПРЯМОВАНІСТЬ ПРОЦЕСУ ВИВЧЕННЯ ІНОЗЕМНОЇ МОВИ}

У статті доведено важливість формування іншомовної комунікативної компетенції у контексті професійної підготовки майбутніх фахівиів, розглядаються умови ефективної реалізаиії комунікативного підходу у прочесі вивчення іноземної мови. У статті висвітлюються проблеми, пов'язані із різними методами та прийомами реалізації комунікативно-орієнтованого навчання. Сутність комунікативного підходу до навчання іноземних мов полягає у тому, шо сам проиес оволодіння мовою має бути своєрідною моделлю прочесу спілкування. Особливого значення набуває комунікативно-діяльнісний підхід до вивчення іноземних мов, який базується на тому, щуо процес навчання є моделлю комунікачї. Комунікативне навчання іноземних мов означає набуття комунікативної компетенції, яка формується у всіх видах мовленнєвої діяльності - говорінні, читанні, аудіюванні та письмі. Розглядаються основні принципи реалізацї комунікативного підходу як комунікативного методу навчання мовленнєвої діяльності.

Ключові слова: іншомовна комунікативна компетенція, професійна підготовка, комунікативний підхід, вивчення іноземної мови.

Formulation of the problem. The need to improve and reform the education system in accordance with international standards is relevant for Ukraine's accession to the world community. The intensification of Ukraine's international relations has supported the training of qualified specialists capable to communicate foreign language with their partners. This is confirmed in educational and professional programs and requires new forms and approaches in the methodology of teaching foreign languages. New tasks include changes in the requirements for the level of language proficiency, the definition of new approaches to the selection of content and organization of material.

The content of the foreign language course is determined by communicative goals and objectives, the focus of training on the development of communicative culture and socio-cultural education, which allows students to be equal partners in intercultural communication in foreign languages in domestic, cultural and professional fields.

The purpose of the article. We believe that in the context of studying communicative learning of foreign languages, further research requires highlighting of problems related to various methods and techniques of communicative-oriented learning, identifying their causes and solutions.

Today, the ultimate goal of learning foreign languages is the formation of foreign language communicative competence, when the student is ready to use a foreign language as a means of speech and mental activity. Such training involves the acquisition of skills to communicate freely in a foreign language environment and the ability to respond adequately in different situations. In order to learn to communicate in a foreign language, it is necessary to create real-life situations (what is called the authenticity of communication) that will stimulate the study of the subject and produce appropriate behavior. It is necessary to prepare students for participation in the process of foreign language communication in the conditions of foreign language communication created in the auditorium. This fact determines the essence of real communication, which confirms that the learning process is a model of the communication process. 
Analysis of recent research and publications. Analyzing the process of education and training of future specialists in the higher education system, the researchers concluded that the formation of skills and abilities of foreign language professional speech is given insufficient attention. The need to solve the problem of optimizing the process of training specialists with knowledge of a foreign language stimulates the scientific search for ways to solve this problem. Based on the research of scientists (I. O. Zimnya, Yu. I. Pasov, N. F. Borisko, I. V. Eremina, A. A. Emelyanova, L. B. Kotlyarova, N. D. Solovyova, G. Brown and others) a general strategy for teaching foreign languages at universities has been developed, which provides for the formation of professional communicative competence in future specialists. Professional communicative competence is defined as the willingness and ability to master subject and scientific knowledge in professional communication [9, p.190].

Presenting main material. Modern requirements for the training of a qualified specialist first of all require him to be a participant in intercultural communication and have the necessary communication skills in professional and situational communication in oral and written forms, skills of practical foreign language skills in various types of speech activities due to professional needs; and be able to master the latest professional information through foreign sources. All these qualities increase the demand for qualified graduates (specialists) who are fluent in a foreign language, including the language of international communication, and necessitates the study of the course "Foreign Language".

Recently, in the practice of teaching foreign languages in higher education institutions, there is a growing tendency to use different approaches to teaching professionally-oriented foreign language communication. The approach is defined as a set of paradigmatic, syntagmatic and pragmatic structures and mechanisms in cognition or practice, which is characterized by competing strategies and programs. There are behavioral, innovative, intuitive-conscious, conscious, individual, thematic, activity, pragmatic, communicative and cognitive approaches [2, p.38].

The communicative-activity approach was determined as a result of comprehension of scientific achievements in the field of linguistics, in particular communicative linguistics, psychology and theory of activity, which was analyzed in works on psychology and methods of teaching foreign languages (O.O. Leontiev, I.O. Zimnya, Yu. I. Passov, S.F. Shatilov, G.V. Rogova and others). The communicative-activity approach is quite effective, so it needs further study and development.

The communicative-activity approach to the study of foreign languages is based on the fact that the learning process is a model of communication. The communicative method of teaching speech activity is based on five principles:

1) the principle of speech and mental activity;

2) the principle of individualization in the leading role of the personal aspect;

3) the principle of functionality;

4) the principle of situationality;

5) principle of novelty.

Communicative orientation of education is a prerequisite for success in the practical study of a foreign language by students. As practice shows, this is largely due to the atmosphere of collective communication, organized on the basis of communicative situations. Situations stimulate students to communicatively motivated speech actions, and communication in such situations allows students to consciously learn foreign language. Dialogic and monologue speech is of great importance. Several participants can be involved in this process. From the standpoint of communicative-activity approach, the process of learning a foreign language is adequate to the real process of communication, i.e. the learning process is a model of the process of communication.

The essence of the communicative approach to learning foreign languages is that the process of learning the foreign language should be a kind of model of the communication process. In this case, communicativeness is considered not as a methodological principle, but as a methodological principle that includes all aspects of learning: the correlation of knowledge with skills, selection of teaching methods, the content of general and educational tasks, and the scope and nature of relationships with others subjects.

The main thing in communicative learning is the focus of the educational process on the development of practical language skills as a means of communication in various life situations depending on the purpose of communication, i.e. on the formation of communicative competence of a certain level. Thus, the whole organization of educational activities should in some way reproduce the process of modeling fundamentally important parameters of communication, such as: the personal nature of the communicative activities of the subjects of communication, relationships and interaction of speech partners; situation as a form of communication, the semantic basis of the communication process; system of speech means that provide communicative activity, the functional nature of the assimilation and use of speech means, heuristics. Usually, this approach to learning a foreign language is called communicative activity. This approach, according to O. O. Leontiev, is focused on the interlocutor, because communicativeness is, after all, the optimal impact on the interlocutor.

According to the communicative-activity approach, communication is the goal, method and means of learning a foreign language. This approach has a deep psycholinguistic conditionality: it is based on the relationship between language and speech activity, psychology of generation and understanding of expressions and focuses on language as a system and speech as an activity to actualize the opportunities that language provides to native speakers. Even F. de Saussure considered language as a sign system that arises and is used for communication and in communication situations, is its main means, i.e. performs a communicative function, in addition, it is a means of transmitting information from speaker to listener. Thus, language is related to the needs and conditions of human communication, is the most important aspect of its social behavior, occupies a certain place in communicative and cognitive activities.

The process of communication is communication in oral or written form, the cognitive essence of which is the exchange of information, its storage and evaluation. Communicative competence is considered to be formed if "the future specialist uses a foreign language to independently get and expand their knowledge and experience" [7, p.28].

Communicativeness involves the speech orientation of the educational process, stimulating speech and mental activity, ensuring the individuality of learning, taking into account the functionality of language, creating situational learning, compliance with the rules of novelty of the educational process. The parameters of communicative communication are realized in the communicative behavior of the teacher, the active behavior of the student, in the subjects of discussion, the use of speech. 
Communicative-oriented learning is possible only under the conditions of the activity approach. Communicative learning is activity-based, as speech communication occurs through speech activity. The principles that reveal this principle include the following:

- activity essence of communicative learning of a foreign language occurs through activity tasks (activities), which are realized with the help of methodical methods (teaching) and create exercises;

- activity tasks are realized on the basis of game, imitation and free communication; there are the following types of tasks: communicative games, communicative imitations, socialization;

- activity essence of communicative-oriented learning is realized in the position "here and now", which is carried out in the classroom: conditions are created for speech and mental creativity of students; the process of foreign language speech thinking is carried out directly at the time of development of the speech situation; foreign language communication is a spontaneous experience;

- methodical organization of training admission is of great importance; Today, a three-phase form of communicative-oriented tasks is widely used, which is that almost any task can be performed in 3 stages: preparatory (pre-activity), executive (while-activity) and final (post-activity);

- the essence of communicative-oriented learning of foreign languages is realized in a humanistic approach to learning: students get the opportunity to freely express their thoughts and feelings, self-expression becomes more important than demonstrating language skills, participants feel safe from criticism and punishment for mistakes, individual violations of language rules and accidental errors are considered to be the norm.

Communicative learning of foreign languages means the acquisition of communicative competence, which is formed in all types of speech activities - speaking, reading, listening and writing.

Communicative-oriented learning of foreign languages is possible in the conditions of authentic process of students' socialization. At the same time, the term "authentic" implies not only the use of "taken from life" educational material in the classroom, but also the creation of methodologically appropriate conditions for natural educational communication. The key positions that reveal the essence of this principle are:

- the use of interactive speech tasks (interactive activities), which are created in such a way that they can not be performed without a partner;

- use of tasks that involve "information inequality";

- authentic learning involves the use of speech and mental tasks, which may be based on: sequence of actions, critical thinking, guessing, finding similarities and differences, etc.;

- the use of organized role communication, which is realized in a role-playing game, which often includes elements of social training, i.e. practice in communication;

- Authentic communicative-oriented learning of foreign languages occurs with the use of spontaneous communication, when the learning situation becomes natural.

It should be noted that currently the communicative-activity approach to learning foreign languages is one of the most important and effective. Thanks to communicative methods, lessons become more interesting. This means that students are interested in further knowledge and learning the language.

Today it cannot be said that all the regularities that allow to effectively teach communicative activity, knowledge, are formed. But we can assure that the basis of the methodological content of modern foreign language lessons should be communicative.

It can be concluded that Ukraine's accession to the Bologna Process has led to radical changes in the educational process of higher education institutions and has set difficult tasks to improve the quality of knowledge of future specialists in foreign languages. The problem of teaching students of the University of professionally-oriented communication in a foreign language is an important component of educational activities that stimulates the formation of skills and abilities of foreign language professionally-oriented communication. Students are fluent in a foreign language and able to form new knowledge based on existing knowledge and various cognitive processes. It is the modern requirements for higher education that justify the use of communicative-activity approach to teaching foreign languages. A special place in the process of teaching students is occupied by motivation, which helps to increase the efficiency and effectiveness of the educational process in higher education.

\section{References:}

1. Korostelev V. S., Passov Ye. I., Kuzovlev V. P. Principles of creating a system of communicative learning of foreign language culture. Foreign languages in school. 1987. № 2. P. 43-44.

2. Methods of teaching foreign languages in secondary schools: Textbook. View. 2nd, ed. and rework. / team of authors under the guidance of S.Yu. Nikolaeva. K .: Lenvit, 2002. 328 p.

3. Methods of teaching foreign languages in secondary schools: textbook / team of authors under the guidance of S. Yu. Nikolaeva. K .: Lenvit, 1999. $320 \mathrm{p}$.

4. Olifer V., Olifer N. New technologies in education. St. Petersburg, 2000. $187 \mathrm{p}$

5. Passov Ye. I. Communicative method of teaching foreign language speech. M., 2001. $212 \mathrm{p}$.

6. Passov Ye. I., Tsarkova V. B. The concept of communicative learning of foreign language culture in high school. M., 1993. 94 p.

7. Stepanova I.S. Implementation of a communicative approach to teaching foreign languages in technical universities: Proceedings of the IX International Scientific and Practical Conference "Humanism and Education". 2008. URL: http://conf.vntu.edu.ua/humed/2008/txt/ stepanova.php.

8. Stoyko S. V. Implementation of communicative approach in teaching foreign languages. Bulletin of the Chernihiv National Pedagogical University. Chernihiv: ChDPU, 2011. Issue. 85 (Series: Pedagogical Sciences). P. 220-223.

9. Surah N. A. Foreign language professional competence: main principles and components of the process of learning professionally oriented communication. Visnyk Luhansk. state ped. University named after T.G. Shevchenko. 2003. № 4 (60). P. 190-192.

10. Surah N. A. Teaching university students professionally oriented communication in a foreign language: Abstract. dis. ... cand. philol. Science: 13.00.04. Lugansk, 2005. 20 p. 